\title{
LH contamination may explain FSH effects on rat Leydig cells
}

\author{
K. Purvis, O. P. F. Clausen* and V. Hansson \\ Institute of Pathology, and ${ }^{*}$ Institute of Forensic Medicine, Rikshospitalet, Oslo, Norway
}

\begin{abstract}
Summary. Treatment of immature, hypophysectomized male rats with $50 \mu \mathrm{g}$ ovine FSH (NIH-FSH-S12) twice a day for 5 days stimulated the maximum quantity of $17 \beta$-hydroxyandrogen produced by isolated Leydig cells in response to hCG. Pretreatment of the FSH preparation with an LH antiserum in one study markedly reduced and in another study completely abolished this stimulatory effect of FSH, but only slightly impaired the capacity of the hormone to stimulate the Sertoli cell in vivo (epididymal androgen-binding protein). Administration of another highly potent FSH preparation (LER-1881) had no discernible effects on the dose-response characteristics of the Leydig cells but was superior to the NIH-FSH-S12 in its capacity for stimulating the Sertoli cell. When all hormone preparations were tested for their ability to stimulate steroid secretion from normal Leydig cells in vitro, a close correlation was obtained between their Leydig cell-stimulating activity (a measure of $\mathrm{LH}$ contamination) and their capacity to alter Leydig cell responsiveness after in-vivo treatment. FSH treatment had no effects on specific LH binding per $10^{6}$ Leydig cells. It is concluded that the stimulatory influence of FSH on rat Leydig cells may to some extent be a result of the LH contaminating the hormone preparation.
\end{abstract}

\section{Introduction}

During the past few years a growing number of investigators have suggested that FSH, in addition to its stimulatory influence on the seminiferous tubules (Sertoli cells) may also exert effects on Leydig cell steroidogenic function. This consideration has largely been prompted by the finding that FSH treatment of hypophysectomized rats results in an increase in the maximum quantity of LH-stimulated androgen secretion by Leydig cells, both in vivo (Odell \& Swerdloff, 1975; Selin \& Moger, 1977) and in vitro (Chen, Payne \& Kelch, 1976; van Beurden, Roodnat, de Jong, Mulder \& van der Molen, 1976; Chen, Shaw \& Payne, 1977). Furthermore, FSH also appears to stimulate the number of LH receptors in testis tissue (Chen et al., 1977). However, interpretation of these apparent effects of FSH is made difficult in light of the fact that the Leydig cell does not possess FSH receptors (de Kretser, Catt \& Paulsen, 1971) and in addition that all of the currently available FSH preparations are contaminated to various degrees with $\mathrm{LH}$.

There are two major aims of the present study: (1) to confirm the stimulatory influence of FSH on Leydig cell function in the hypophysectomized immature rat, and (2) to determine whether this influence could be partly or wholly explained by contamination of the hormone preparation with small quantities of $\mathrm{LH}$.

\section{Materials and Methods}

\section{Animals and treatments}

Immature male rats, hypophysectomized on Day 29 after birth, were purchased from Hormone Assay Laboratory, Chicago. Hormone treatments began immediately on the day of arrival (Day 31), 2 days after hypophysectomy. 
Study 1. Hypophysectomized rats (50) were divided equally into 5 groups and treated with the following: Group A (controls), saline $(9 \mathrm{~g} \mathrm{NaCl} / \mathrm{l})$; Group B, $50 \mu \mathrm{g}$ ovine FSH (oFSH, NIHS12); Group C, $50 \mu \mathrm{g}$ oFSH pretreated with LH antiserum; Group D, $1 \mu \mathrm{g}$ ovine LH (oLH, NIH-S20); Group E, $1 \mu \mathrm{g}$ oLH pretreated with LH antiserum. All preparations were injected subcutaneously in $0.1 \mathrm{ml}$ volumes twice a day for 5 days. All the animals were killed $24 \mathrm{~h}$ after the last injection and the testes were removed for the preparation of enriched Leydig cell suspensions.

Study 2. Hypophysectomized rats (48) were divided equally into 4 groups and treated with the following: Group A (controls), saline; Group B, $50 \mu \mathrm{g}$ oFSH (NIH-S12); Group C, $50 \mu \mathrm{g}$ oFSH pretreated with LH antiserum; Group D, $1.6 \mu \mathrm{g}$ purified oFSH (LER-1881). All preparations were administered as described in Study 1.

\section{Treatment with $L H$ antiserum}

The $\mathrm{LH}$ antiserum was raised against oLH in rabbits and $50 \mu \mathrm{l}$ of this serum neutralized 10 $\mu \mathrm{g}$ NIH-LH-S18. Details concerning the monospecificity of this antiserum are presented elsewhere (Madhwa Raj \& Moudgal, 1970). Since most NIH-FSH preparations have LH contamination of $<1 \%$ it was assumed that the $50 \mu \mathrm{g}$ oFSH dose contained less than $0.5 \mu \mathrm{g}$ contaminating $\mathrm{LH}$. The freeze-dried oFSH $(10 \mathrm{mg})$ was first dissolved in $500 \mu$ phosphate-

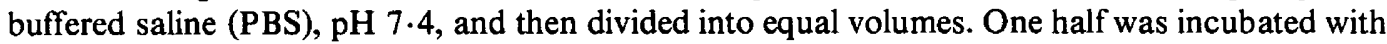
$250 \mu \mathrm{LH}$ antiserum at $4^{\circ} \mathrm{C}$ for $3 \mathrm{~h}$ whilst the remaining half was incubated under identical conditions with the same volume of normal rabbit serum. After incubation, the LH-antibody complexes were precipitated by centrifugation $(4000 \mathrm{~g}, 10 \mathrm{~min})$ and the supernatants were then diluted with PBS containing $0.1 \%$ bovine serum albumin (BSA) to give a final concentration of $50 \mu \mathrm{g} \mathrm{oFSH} / 0.1 \mathrm{ml}$. It was assumed that no loss of FSH had occurred during the incubation. In the case of the antibody-treated oLH, the volume of antiserum was adjusted to neutralize all of the $\mathrm{LH}$ activity in the preparation $(1 \mathrm{ml}$ antiserum incubated with $200 \mu \mathrm{g} \mathrm{oLH}$ in $0.1 \mathrm{ml}$ ).

\section{Choice of hormone doses to be injected}

Ovine FSH was administered at a dose level ( $50 \mu \mathrm{g} /$ injection) which had earlier been shown to elicit a half-maximal response from the Sertoli cell (androgen-binding protein secretion) in vivo under similar conditions (Hansson et al., 1976b). It was assumed that this dose of FSH would contain less than $0.5 \mu \mathrm{g} \mathrm{LH}$ contamination $(<1 \%)$. A slightly higher dose of oLH $(1 \mu \mathrm{g} /$ injection) was administered for comparison. The purified oFSH preparation (LER-1881) has been shown to have a bioassay potency (Steelman-Pohley assay) approximately 30 times higher than that of the crude oFSH. The dose of this potent preparation was therefore adjusted so as to give effects in vivo comparable to those of $50 \mu \mathrm{g} \mathrm{oFSH}$, i.e. $1.6 \mu \mathrm{gER}$-1881/injection.

\section{Preparation of enriched Leydig cell suspensions}

Enriched Leydig cell suspensions were prepared as described previously (Purvis, Clausen \& Hansson, 1978b; Purvis, Clausen, Brandtzaeg \& Hansson, 1978a). The number of Leydig cells present in each incubation tube was calculated after a nucleated cell count and determination of the percentage of $3 \beta$-hydroxysteroid dehydrogenase ( $3 \beta$-HSD) positive cells (i.e. Leydig cells) present. The androgen response could thus be expressed per $10^{6}$ Leydig cells.

\section{Binding of ${ }^{125}$ I-labelled hLH to Leydig cells}

Aliquots $(200 \mu \mathrm{l})$ of the cell suspensions were incubated with 100000 c.p.m. of iodinated human LH ( ${ }^{125}$ I-labelled hLH: sp. act. $\left.50 \mu \mathrm{Ci} / \mu \mathrm{g}\right)$ with various quantities of unlabelled human 
LH (LER 960) at $33^{\circ} \mathrm{C}$ for $2.5 \mathrm{~h}$ in a total volume of $350 \mu \mathrm{l}$. After this time, the cells were washed twice in $2 \mathrm{ml}$ ice-cold phosphate-buffered saline, $\mathrm{pH} 7.4$, containing $0.1 \% \mathrm{BSA}$, and centrifuged at $1500 \mathrm{~g}$ for $30 \mathrm{~min}$. The pellets were counted in a Searle $1285 \mathrm{Gamma}$ counter with $70 \%$ efficiency. Incubation of the tracer in the presence of $10 \mu \mathrm{g}$ unlabelled LH (NIH-LH-S 19) provided an assessment of non-specific binding. Calculation of the number of binding sites in the preparation was by Scatchard analysis (Scatchard, 1949) and the results were expressed as fmol

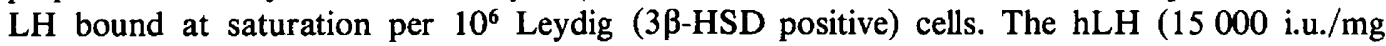
determined by radioimmunoassay, (see Sand \& Torjesen, 1973 for details)) was iodinated by using the sodium hypochlorite method (Redshaw \& Lynch, 1974), and when 20000 c.p.m. ${ }^{125 I-}$ labelled hLH were exposed to an excess of testicular particles $(27000 \mathrm{~g}$ pellet of testis homogenate), approximately $60-70 \%$ of the tracer was specifically bound.

\section{In-vitro assay of Leydig cell-stimulating activity of the hormone preparations}

To assess the LH activity of the different hormone preparations an aliquot of the solutions to be injected was added in different dilutions to a Leydig cell suspension prepared from normal 30day-old rats. The incubations were performed in triplicate at $34^{\circ} \mathrm{C}$ for $3 \mathrm{~h}$ in a shaking incubator in $95 \% \mathrm{O}_{2}: 5 \% \mathrm{CO}_{2}$. The quantity of androgen produced by the Leydig cells in response to the different preparations was determined as described below. On this occasion the number of Leydig cells present in each incubation tube was not determined and the response was simply expressed in terms of androgen produced per flask.

\section{Measurement of epididymal androgen-binding protein $(A B P)$}

The epididymides were removed from each animal, defatted, pooled and weighed. A cytosol was then prepared from an homogenate of the pooled organs and subjected to polyacrylamide gel electrophoresis in triplicate for the measurement of ABP. The details of this technique have been published elsewhere (Ritzén, French, Weddington, Nayfeh \& Hansson, 1974; Purvis \& Hansson, 1978).

\section{Assay of androgen}

The steroidogenic response was evaluated by measuring the production of $17 \beta$ hydroxyandrogen. A previous study (Purvis et al., 1978b) showed that the steroid secreted by Leydig cells from immature intact and short-term hypophysectomized male rats is predominantly $5 \alpha$-androstane- $3 \alpha, 17 \beta$-diol and not testosterone. The measurement of $17 \beta$-hydroxyandrogens therefore involved the determination not only of testosterone but also the $5 \alpha$-reduced androgens, $5 \alpha$-androstane- $3 \beta, 17 \beta$-diol and dihydrotestosterone. The assay of $17 \beta$-hydroxyandrogen produced in response to the hCG was then expressed per $10^{6} 3 \beta$-HSD-positive cells.

\section{Other analytical techniques}

Protein was measured by the method of Lowry, Rosebrough, Farr \& Randall (1951).

\section{Results}

In-vitro response of Leydig cells to $h C G$

Study 1 . The effects of the different hormone preparations on the subsequent in-vitro response of isolated Leydig cells to hCG are shown in Text-fig. 1(a). Treatment with oFSH (Group B) in vivo almost doubled the quantity of androgen produced by the Leydig cells under 
conditions of maximum stimulation with hCG in vitro. Pretreatment of the FSH with LH antiserum (Group C) markedly reduced this stimulatory effect. Similar treatment with oLH (Group D) evoked similar alterations in the maximum quantity of androgen produced by the Leydig cells, but treatment with the $\mathrm{LH}$ antiserum (Group E) did not abolish this stimulatory influence, since the antiserum did not absorb all the ovine LH under the conditions used (see below). None of the hormone preparations had obvious effects on the sensitivity (dose of hCG eliciting a half-maximal response, $\mathrm{ED}_{50}$ ) of the Leydig cell to hCG.

Study 2. As found in Study 1, treatment with $50 \mu \mathrm{g}$ oFSH (Group B) stimulated (by approximately $70 \%$ ) the maximum quantity of androgen produced, and, absorption of the oFSH with the LH antiserum (Group C) completely abolished the effect (Text-fig. Hb). The purified FSH preparation (Group D) had no detectable effects at the dose level used.

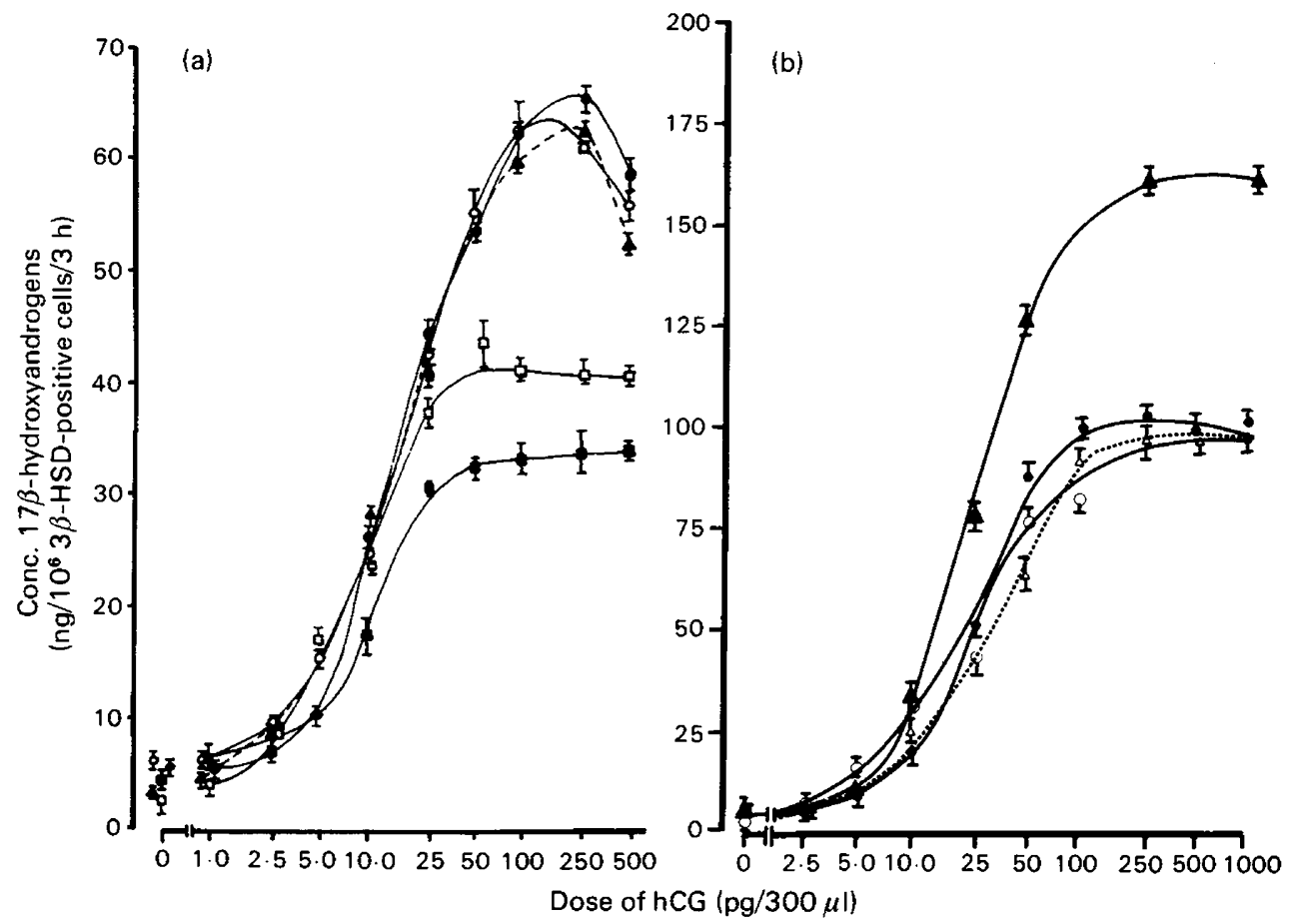

Text-fig. 1. The androgen response in vitro to increasing doses of hCG of Leydig cells from hypophysectomized rats after treatment (twice daily for 5 days) with various hormones in (a) Study 1 and (b) Study 2. (a) Group A, $\mathbf{v}=$ saline control; Group B, $O=50 \mu \mathrm{g}$ FSH; Group C, $\square=50 \mu \mathrm{g}$ oFSH pretreated with LH antiserum; Group D, $\bigcirc=1 \mu \mathrm{g}$ oLH; Group E, $\Delta=1 \mu \mathrm{g}$ oLH pretreated with LH antiserum. (b) Group $A, O=$ saline control; Group $B, \Delta=50 \mu g$ oFSH; Group C, $\Delta=50 \mu \mathrm{g}$ oFSH pretreated with LH antiserum; Group D, $\ominus=1.6 \mu \mathrm{g}$ purified oFSH. The values are mean \pm s.d. of triplicate incubations.

\section{Binding of ${ }^{125}$ I-labelled $h L H$ to Leydig cells}

Study 1. Scatchard analysis revealed no major changes in the average number of LH receptors per Leydig cell (as indicated by the intercepts of the plots with the $x$ axes) after the different hormone treatments (Text-fig. 2). The parallel slopes of all Scatchard plots indicated that no alteration in the affinity of the $\mathrm{LH}$ receptors had occurred as a result of the hormone treatments. The average $K_{d}$ was $9 \times 10^{-10} \mathrm{M}$, assuming a molecular weight for $\mathrm{LH}$ of 40000 and that all the $\mathrm{LH}$ was biologically active. 

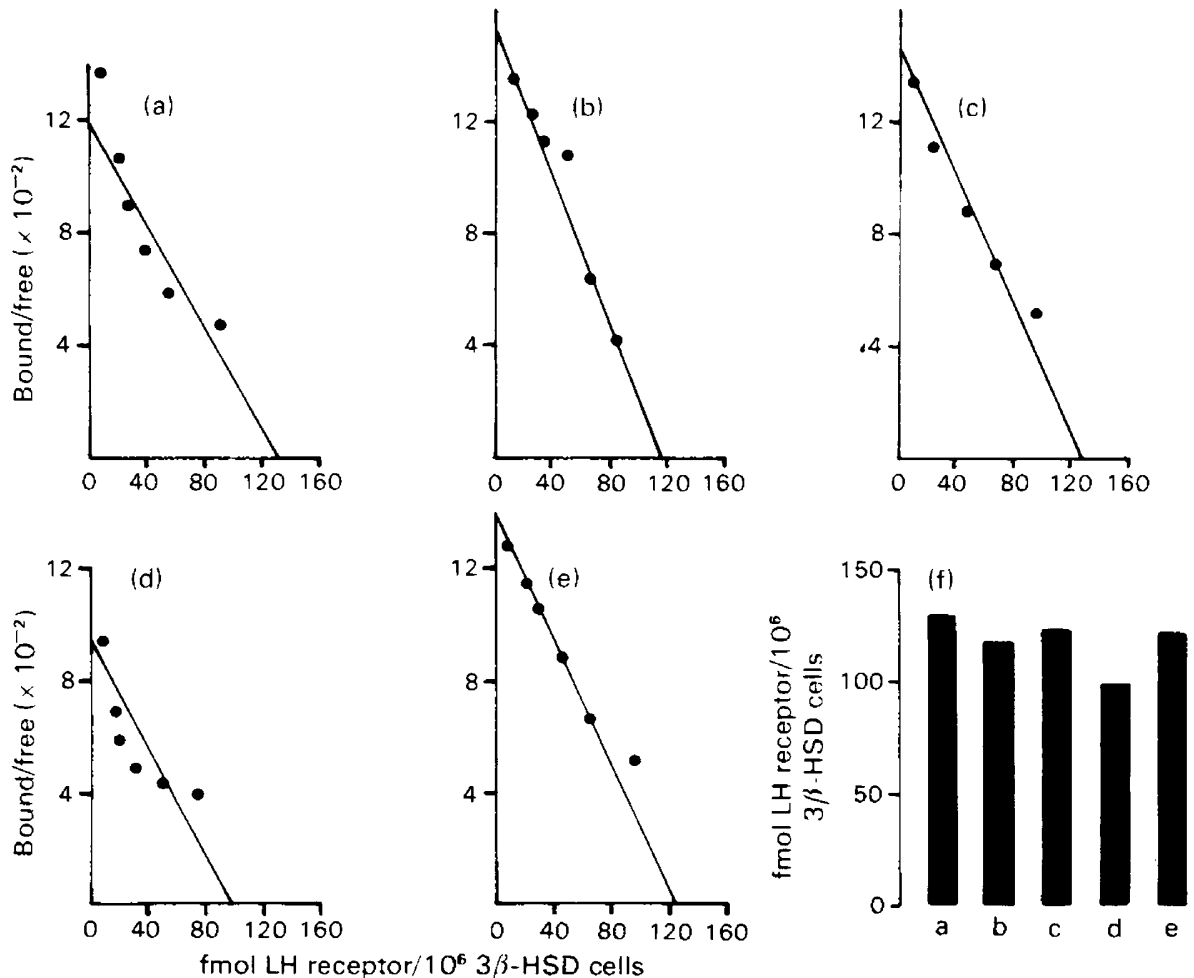

Text-fig. 2. Scatchard plots of binding of ${ }^{125} \mathrm{I}$-labelled hLH to isolated Leydig cells from hypophysectomized rats treated with (a) saline-Group A; (b) $50 \mu \mathrm{g}$ oFSH-Group B; (c) $50 \mu \mathrm{g}$ oFSH pretreated with antiserum to LH-Group C; (d) $1 \mu \mathrm{g}$ oLH-Group D; (e) $1 \mu \mathrm{g}$ oLH pretreated with antiserum to LH-Group E. (f) Diagram summarizing the data from the Scatchard analyses.

\section{Effects on Sertoli cell function (Table 1)}

Study 1. Although there were no discernible effects on ABP secretion (Sertoli cell function) in Groups D and E, FSH caused a marked stimulation in the levels of ABP (Group B), an effect which was only slightly reduced by prior treatment of the preparation with the LH antiserum (Group C).

Study 2. Treatment with the LH antiserum had little effect on the biological activity of the FSH preparation in vivo (Groups B and C). The effect of the LER-1881 preparation (Group D) was greater than that of the oFSH used in Group B.

\section{Leydig cell-stimulating activity of hormone preparations}

Study 1 . The LH-like activity of the hormone preparations in vitro is demonstrated in Textfig. 3. The level of the LH contamination in the oFSH (Group B) amounted to only $0.031 \%$ of the mass of hormone present $(650 \mathrm{ng}$ oFSH stimulated a response from the Leydig cells equivalent to $0.22 \mathrm{ng} \mathrm{oLH}$ ), suggesting that only about $15 \mathrm{ng} \mathrm{oLH}$ were administered for each injection of $50 \mu \mathrm{g} \mathrm{oFSH}$. Pretreatment of the oFSH with the $\mathrm{LH}$ antiserum (Group C) removed all trace of Leydig cell-stimulating activity, but pretreatment of the oLH with LH antiserum (Group E) did not completely remove all the LH from the preparation: approximately $2 \%$ of the LH activity still remained ( $22 \mathrm{ng}$ ) and this was sufficient to mimic the effect of $50 \mu \mathrm{g}$ oFSH (NIH-S12). 
Table 1. Epididymal levels of androgen-binding protein (ABP) in hypophysectomized rats treated with various hormone preparations

\begin{tabular}{cclc}
\hline Study & Group & \multicolumn{1}{c}{ Treatment } & $\begin{array}{c}\text { ABP } \\
\text { (pmol/epididymis)* }\end{array}$ \\
\hline 1 & A & Control & 0.12 \\
& B & oFSH (NIH-S12) & $2 \cdot 01$ \\
& C & oFSH + LH antiserum & 1.35 \\
& D & oLH & 0.11 \\
& E & oLH + LH antiserum & $0 \cdot 11$ \\
2 & & & \\
& A & Control & 0.15 \\
& B & oFSH (NIH-S12) & 0.90 \\
& C & oFSH + LH antiserum & 0.61 \\
& D & oFSH (LER 1881) & 1.15 \\
\hline
\end{tabular}

* Determinations were carried out in triplicate on pools containing the epididymides from at least 8 rats. The coefficient of variation of replicates never exceeded $5 \%$.

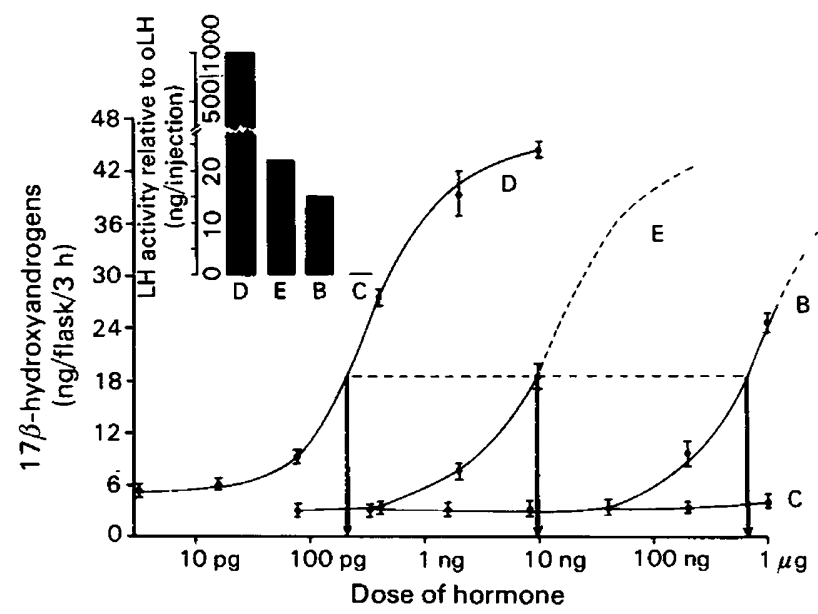

Text-fig. 3. The LH-like activity of the various hormone preparations used in Study 1 (see legend to Text-fig. 1a). Activity was assessed by exposing normal Leydig cells from immature rats to various dilutions of the preparations in vitro. The vertical arrows indicate the quantity of LH present in each preparation relative to the activity of the oLH (see summary in inset figure).

Vertical bars represent s.d. of triplicate incubations.

Study 2. As shown in Text-fig. 4 the LER-1881 preparation (Group D) had slightly more LH activity on a weight basis than did the oFSH (Group B). Pretreatment of oFSH with the LH antiserum (Group C) removed approximately $98 \%$ of the LH contamination.

\section{Discussion}

The present study confirms the observation that FSH treatment of hypophysectomized rats in vivo results in an enhancement in the maximum quantity of androgen secreted by the Leydig cells in vitro in response to hCG. However, two observations suggest that this positive influence is a manifestation of small quantities of $\mathbf{L H}$ contaminating the hormone preparation. Pretreatment of the FSH with an LH antiserum abolished these stimulatory effects and this loss in efficacy was correlated with the complete removal of the capacity of FSH to stimulate steroid 


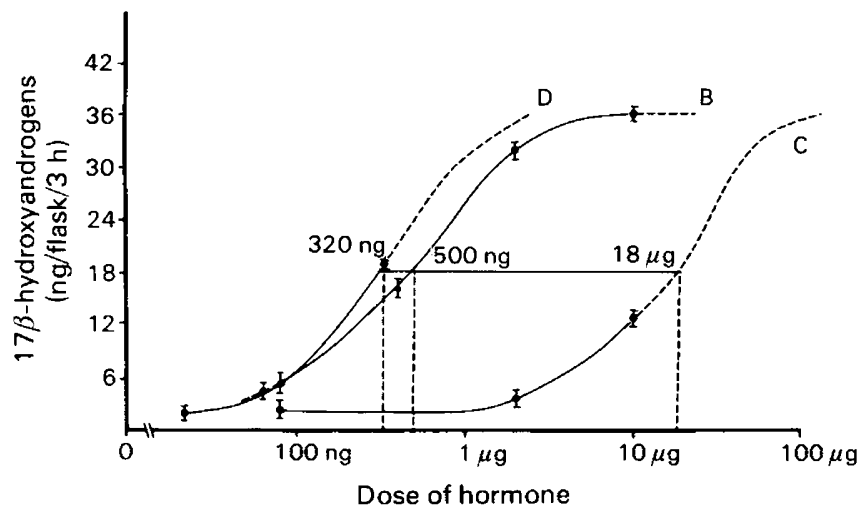

Text-fig. 4. The LH-like activity of the various hormone preparations used in Study 2 (see legend to Text-fig. $1 \mathrm{~b}$ ). The vertical broken lines represent the relative quantity of LH contaminating the preparations. Vertical bars represent s.d. of triplicate incubations.

secretion directly from normal Leydig cells in vitro (a measure of its $\mathbf{L H}$ contamination). The fact that this antiserum treatment only slightly impaired the capacity for the FSH to stimulate Sertoli cell function in vivo in the same animals (as revealed by the quantity of ABP present in the epididymides) rules out the possibility that this loss of effect was due to a non-specific removal of biologically active FSH by the LH antiserum. The small decrease in FSH efficacy observed after antiserum treatment may simply reflect the withdrawal of an androgen stimulus (via removal of the contaminating $\mathrm{LH}$ ). The second observation which made the possibility of FSH-Leydig cell interaction unlikely was that the preparation with the greatest FSH potency in vivo (LER-1881) with regard to Sertoli cell function had no discernible effects on the in-vitro dose-response characteristics of the Leydig cells in the same animals. Although the level of LH contamination in this preparation was high, if not higher than that of the oFSH when expressed per unit weight, its much greater FSH potency enabled it to be used at a dose level approximately 1:30 that of the crude preparation, thus reducing the $\mathbf{L H}$ content to negligible levels. The fact that in both studies the $\mathrm{LH}$ antiserum was effectively able to remove almost all the $\mathrm{LH}$ activity from the FSH preparation suggests that the Leydig cell-stimulating activity of these preparations is mainly due to $\mathrm{LH}$ contamination and not to an intrinsic LH-like activity.

It is difficult to provide a single explanation for the apparent discrepancies between our work and that of others. Van Beurden et al. (1976) showed that continuous administration of the expected contaminating amount of oLH (600 ng/day) in the oFSH preparation had no effect on the in-vitro response of Leydig cells from immature, hypophysectomized rats to $\mathrm{LH}$ nor did it increase the effect observed with a supposedly pure rat FSH preparation (containing $<0.1 \%$ LH). Apart from the fact that the dose of $\mathrm{LH}$ administered was lower, it may be significant that the preparation was injected daily and not, as in our case, twice daily. The possibility that such small doses of $\mathrm{LH}$ are rapidly metabolized (unless some degree of protection is conferred on it by being injected as a contaminant in a much larger quantity of FSH) is very real, and multiple injections may be necessary to achieve an adequate blood level of LH. The rats were also hypophysectomized at an earlier age (21-25 days) than the present study; this is a critical period for Leydig cell development and these small differences in age may therefore be important. Selin \& Moger (1977) found that $1.5 \mu \mathrm{g} \mathrm{LH/day,} \mathrm{a} \mathrm{dose} \mathrm{comparable} \mathrm{to} \mathrm{that} \mathrm{which} \mathrm{we} \mathrm{used,} \mathrm{resulted}$ in a significant increase in the subsequent testicular response of hypophysectomized rats to $\mathrm{LH}$ in vivo. However, the effect was not as great as that with FSH $(42.5 \mu \mathrm{g} /$ day $)$ which contained this quantity of $\mathrm{LH}$ as contamination. The problem with testing the response of the Leydig cells in vivo is that it is also potentially subject to effects via the seminiferous tubules. In hypophysectomized rats the tubules are atrophic and the Leydig cell response to $\mathrm{FSH}+$ 
contaminating LH may differ from that induced by LH alone. Another major difference between our own work and that of others is that in all other studies testosterone has been used as the indicator of steroid response rather than $17 \beta$-hydroxyandrogen secretion, which measures a greater proportion of the androgen secreted. It may well be that FSH causes a qualitative change in the conversion of testosterone to dihydrotestosterone and androstanediol.

If the observed FSH effects can be explained by contaminating $\mathrm{LH}$, the extremely small quantities of $\mathrm{LH}$ which are involved in this priming effect are of great interest. With the in-vitro Leydig cell bioassay, $50 \mu \mathrm{g}$ crude oFSH had quantities of contaminating LH equivalent to $15 \mathrm{ng}$ oLH (approximately $0.03 \%$ ) which were apparently sufficient to account for the observed effects on the Leydig cell response. Moreover, in one of the control preparations in Study 1, although the LH antiserum removed more than $95 \%$ of the biologically active LH from the oLH preparation, enough LH still remained (amounting to $20 \mathrm{ng} /$ injection) to have a pronounced effect on the response of the Leydig cells. Such priming effects of small doses of LH on Leydig cell responsiveness have recently been reported for the immature monkey (Arslan, Zaidi \& Qazi, 1978). In the study of Arslan et al. (1978), the doses of LH were not large enough to stimulate peripheral plasma testosterone levels but did cause a stimulation in the maximum steroidogenic response to $\mathrm{LH}$ from the testis tissue in vitro. There has been much speculation that, at least in the rat, the gradual acquisition of $\mathrm{LH}$ responsiveness by the Leydig cell during early development is the result of an increase in FSH secretion. It now appears that normal Leydig cell responsiveness to LH may be the result of small, priming doses of LH secreted during the early phases of development, possibly acting synergistically with prolactin (Negro-Vilar, Krulich \& McCann, 1973). Such priming probably takes place before 30 days of age since by this time the rat Leydig cell has already acquired its maximum responsiveness to LH (Purvis et al., 1978b). Indeed, it has long been recognized that several of the major steroidogenic enzymes in the Leydig cell are under LH control (Samuels \& Helmreich, 1956; Menon, Dorfman \& Forchielli, 1967; Shikita \& Hall, 1967; Purvis et al., 1973) and it is therefore not surprising that exposure to low doses of this hormone may have beneficial effects. On the other hand, higher doses of LH may be inhibitory and cause an attenuated response from the Leydig cell (Tsuruhara, Dufau, Cigorraga \& Catt, 1977; Purvis, Torjesen, Haug \& Hansson, 1977; Purvis et al., 1978b; Sharpe \& McNeilly, 1978). This desensitization phenomenon is now becoming increasingly accepted as a physiological process by which the target tissue can adjust its responsiveness depending on the levels of trophic hormone. It therefore becomes important to distinguish between priming doses of LH and the higher doses which are responsible for these negative effects. Chen et al. (1977) have shown that FSH treatment increases the number of $\mathrm{LH}$ receptors in testis tissue from hypophysectomized rats, but we could not confirm this observation in the present study. Chen $e t$ al. (1977) used testis tissue and not isolated cells and therefore had no control over the number of Leydig cells under investigation. It is possible that the contaminating $\mathrm{LH}$ in the FSH preparation may cause the appearance of new Leydig cells with additional receptor complements. Another possibility is that FSH treatment of hypophysectomized animals may reduce proteolyicic activity in the tubules and thus cause an apparent increase in the number of LH receptors measured. Although the above studies tend to suggest that FSH has no direct effect on the Leydig cell, they obviously do not preclude the possibility that FSH may exert an indirect effect on the Sertoli cell at least at some stage in development. The influence of the Leydig cell on Sertoli cell function (via androgens) is well established (Hansson, Calandra, Purvis, Ritzén \& French, 1976a) and it is an attractive hypothesis that some local feedback mechanisms may operate in the opposite direction to co-ordinate tubular events with androgen secretion.

This work was supported by grants from the World Health Organisation, The Population Council (New York), the Norwegian Society for Fighting Cancer and the Norwegian Research Council for Science and the Humanities (NAVF). We thank P. Torjesen and NIAMDD for the 
gifts of LH; Dr H. Madhwa Raj for his generous gift of LH antiserum; Dr L. Reichert for providing us with the highly purified oFSH preparation (LER-1881); Anita Olsen and Drude Andersen for skilled technical help; and Liv Støttum for typing the manuscript.

\section{References}

Arslan, M., Zaidi, A.A. \& Qazi, M.H. (1978) Effect of gonadotropins and $\mathbf{L} H-\mathrm{RH}$ on functional differentiation of immature monkey testis. In Endocrine Approach to Male Contraception, pp. 319-328. Eds V. Hansson, K. Purvis, E. M. Ritzén \& F. S. French. Scriptor, Copenhagen.

Chen, Y.-D. I., Payne, A. H. \& Kelch, R.P. (1976) FSH stimulation of Leydig cell function in the hypophysectomized immature rat. Proc. Soc. exp. Biol. Med. 153, 473-475.

Chen, Y.-D.I., Shaw, M.J. \& Payne, A.H. (1977) Steroid and FSH action on LH-sensitive testicular responsiveness during sexual maturation of the rat. Mol. cell. Endocr. 8, 291-299.

de Kretser, D.M., Catt, K.J. \& Paulsen, C.A. (1971) Studies on the in vitro testicular binding of iodinated Luteinizing Hormone in rats. Endocrinology 88, 332-337.

Hansson, V., Calandra, R., Purvis, K., Ritzén, M. \& French, F.S. (1976a) Hormonal regulation of spermatogenesis. Vitams Horm. 34, 187-214.

Hansson, V., Purvis, K., Calandra, R., French, F.S., Kotite, N., Nayfeh, S.N., Ritzén, E.M. \& Hagenäs, L. (1976b) The hormonal specificity of the production and secretion of testicular androgen binding protein (ABP) from Sertoli cells. Proc. 5th Int. Congr. Endocrinology, Vol. 1, pp. 410-416. Ed. V. H. T. James. Excerpta Medica, Amsterdam.

Lowry, O.H., Rosebrough, N.J., Farr, A.L. \& Randall, R.J. (1951) Protein measurement with the Folin phenol reagent. J. biol. Chem. 193, 265-275.

Madhwa Raj, H.G. \& Moudgal, N.R. (1970) Hormonal control of pregnancy in the intact rat. Endocrinology 86, 874-889.

Menon, K.M.J., Dorfman, R.I. \& Forchielli, E. (1967) Influence of gonadotropins on the cholesterol sidechain cleavage reaction by rat testis mitochondrial preparations. Biochim. biophys. Acta 148, 486-494.

Negro-Vilar, A., Krulich, L. \& McCann, S.M. (1973) Changes in serum prolactin and gonadotropins during development of the male rat. Endocrinology 93, $660-664$.

Odell, W.O. \& Swerdloff, R.S. (1975) The role of testicular sensitivity to gonadotropins in sexual maturation of the male rat. J. Steroid Biochem. 6, 853-857.

Purvis, K. \& Hansson, V. (1978) Androgens and androgen binding protein in the rat epididymis. $J$. Reprod. Fert. 52, 59-63.

Purvis, J.L., Canick, J.A., Latif, S.A., Rosenbaum, J.H., Hologgitas, J. \& Menard, R.H. (1973) Lifetime of microsomal cytochrome P-450 and steroidogenic enzymes in rat testis as influenced by human chorionic gonadotropin. Archs Biochem. Biophys. 159, 39-49.
Purvis, K., Torjesen, P.A., Haug, E. \& Hansson, V. (1977) hCG suppression of LH receptors and Leydig cell responsiveness to hCG. Mol. cell. Endocr. 8, 73-80.

Purvis, K., Clausen, O.P.F., Brandtzaeg, P. \& Hansson, V. (1978a) LH receptors and Leydig cell responsiveness to hCG in vitro. Archs Andrology 1, 299310.

Purvis, K., Clausen, O.P.F. \& Hansson, V. (1978b) Agerelated changes in responsiveness of rat Leydig cells to hCG. J. Reprod. Fert. 52, 379-386.

Redshaw, M.R. \& Lynch, S.S. (1974) An improved method for the preparation of iodinated antigens for radioimmunoassay. $J$. Endocr. 60, 527-528.

Ritzén, E.M., French, F.S., Weddington, S.C., Nayfeh, S.N. \& Hansson, V. (1974) Steroid binding in polyacrylamide gels. Quantitation at steady state conditions. J. biol. Chem. 249, 6597-6604.

Samuels, L.T. \& Helmreich, M.L. (1956) The influence of chorionic gonadotropin on the $3 \beta$-ol dehydrogenase activity of testes and adrenals. Endocrinology $58,435-442$.

Sand, T. \& Torjesen, P.A. (1973) Dextran-coated charcoal used in the radioimmunoassay of human pituitary luteinizing hormone. Acta endocr., Copenh. 73, 444-454.

Scatchard, G. (1949) The attractions of proteins for small molecules and ions. Ann. N.Y. Acad. Sci. 51, 660-672.

Selin, L.K. \& Moger, W.H. (1977) The effect of FSH on LH induced testosterone secretion in the immature hypophysectomized male rat. Endocr. Res. Commun. 4, $171-182$.

Sharpe, R.M. \& McNeilly, A.S. (1978) Gonadotropininduced reduction in LH-receptors and steroidogenic responsiveness of the immature rat testis. In Endocrine Approach to Male Contraception, pp. 264-274. Eds V. Hansson, K. Purvis, E. M. Ritzén \& F. S. French. Scriptor, Copenhagen.

Shikita, M. \& Hall, P.F. (1967) Action of human chorionic gonadotropin in vivo upon microsomal enzymes in testes of hypophysectomized rats. Biochim. biophys. Acta 141, 433-435.

Tsuruhara, T., Dufau, M.L., Cigorraga, S. \& Catt, K.J. (1977) Hormonal regulation of testicular luteinizing hormone receptors. Effects of cyclic AMP and testosterone responses in isolated Leydig cells. J. biol. Chem. 252, 9002-9009.

van Beurden, W.M.O., Roodnat, B., de Jong, F.H. Mulder, E. \& van der Molen, H. (1976) Hormonal regulation of $\mathrm{LH}$ stimulation of testosterone production in isolated Leydig cells of immature rats: the effect of hypophysectomy, FSH, and estradiol-17\% Steroids 28, 847-866. 